\title{
Crescentic glomerulonephritis in ANCA associated vasculitis
}

Citation for published version (APA):

Hilhorst, M. L. (2015). Crescentic glomerulonephritis in ANCA associated vasculitis. [Doctoral Thesis, Maastricht University]. Uitgeverij BOXPress. https://doi.org/10.26481/dis.20150924mh

Document status and date:

Published: 01/01/2015

DOI:

10.26481/dis.20150924mh

Document Version:

Publisher's PDF, also known as Version of record

\section{Please check the document version of this publication:}

- A submitted manuscript is the version of the article upon submission and before peer-review. There can be important differences between the submitted version and the official published version of record.

People interested in the research are advised to contact the author for the final version of the publication, or visit the DOI to the publisher's website.

- The final author version and the galley proof are versions of the publication after peer review.

- The final published version features the final layout of the paper including the volume, issue and page numbers.

Link to publication

\footnotetext{
General rights rights.

- You may freely distribute the URL identifying the publication in the public portal. please follow below link for the End User Agreement:

www.umlib.nl/taverne-license

Take down policy

If you believe that this document breaches copyright please contact us at:

repository@maastrichtuniversity.nl

providing details and we will investigate your claim.
}

Copyright and moral rights for the publications made accessible in the public portal are retained by the authors and/or other copyright owners and it is a condition of accessing publications that users recognise and abide by the legal requirements associated with these

- Users may download and print one copy of any publication from the public portal for the purpose of private study or research.

- You may not further distribute the material or use it for any profit-making activity or commercial gain

If the publication is distributed under the terms of Article $25 \mathrm{fa}$ of the Dutch Copyright Act, indicated by the "Taverne" license above, 


\section{Postulations of this thesis - Stellingen behorende bij dit proefschrift}

1. Proteinase-3 ANCA and myeloperoxidase ANCA should form the basis of distinguishing ANCA associated vasculitis, not the clinical phenotypes granulomatosis with polayngiitis or microscopic polyangiitis (this thesis)

2. The patient and renal survival rates of patients with ANCA associated vasculitis have improved considerably in the Limburg region over the last 10 years. (this thesis)

3. A percentage of normal glomeruli below $25 \%$ in a renal biopsy from a patient with active ANCA associated vasculitis bears a $50 \%$ chance of future need for dialysis. (this thesis)

4. Circulating connective tissue growth factor predicts the future amount of cicatrized lesions in kidneys of patients with ANCA associated glomerulonephritis. (this thesis)

5. HLA-DPB $1 * 0401$ carriage in patients with ANCA associated vasculitis results in an increased propensity to flare. (this thesis)

6. Episodes of hypercoagulability as a result of dysfunctional endothelium in patients with ANCA associated vasculitis in remission contribute to the protracted risk for a thromboembolic event. (this thesis)

7. "Was du ererbt von Deinen Vätern hast, erwirb es, um es zu besitzen. „, Johann Wolfgang von Goethe

8. "Success is not final, failure is not fatal: it is the courage to continue that counts." Sir Winston Churchill

9. "Someone is sitting in the shade today because someone planted a tree a long time ago." Warren Buffett

10. "So long as you have food in your mouth, you have solved all questions for the time being." Franz Kafka 